\title{
POHREBISKÁ ÚNĚTICKEJ KULTÚRY V NOVÝCH ZÁMKOCH
}

\author{
J A K U B G O D I Š
}

\begin{abstract}
Burial Sites of Únětice Culture in Nové Zámky. This paper aims to publish a summary of previously known, yet so far unpublished Únětice culture grave findings from within the town limits of Nové Zámky, which unequivocally show a dense and stable settlement network in this microregion. There are presented inhumation burials documented during field excavations of the local regional museum (presently Ján Thain Museum) in the areas of Žofijská osada and Paneláreň, as well as older rescue excavations of the Institute of Archaeology SAS in Nitra in the areas of Tehelňa and Ragoňa.
\end{abstract}

Keywords: Southern Slovakia, Early Bronze Age, Únětice culture, burial ground.

Príspevok je zameraný na sprístupnenie a vyhodnotenie doposial' nezverejnených hrobových nálezov únětickej kultúry v Nových Zámkoch. Tie boli dokumentované pri terénnych akciách pod vedením bývalých archeológov miestneho regionálneho múzea (dnes Múzeum Jána Thaina) v polohách Paneláreň a Žofijská osada. Pri tejto príležitosti sú predmetom diskusie i niektoré už dávnejšie známe hrobové celky objavené pri výskumoch Archeologického ústavu SAV v polohách Tehelňa a Ragoňa. Menované náleziská $\mathrm{v}$ súčasnosti ležia $\mathrm{v}$ čiastočne zastavaných okrajových zónach intravilánu mesta (obr. 1).

Pri rekonštrukcii budovy panelárne Pozemných stavieb Nitra - závod Nové Zámky, nachádzajúcej sa pri Bešeňovskej ceste, bol v marci 1989 porušený hrob jedinca v skrčenej polohe (obr. 1: 3). Objav bol nahlásený pracovníkom závodu F. Škoríkom do vtedajšieho Okresného múzea v Nových Zámkoch, ktorý zároveň odovzdal aj získané nálezy. ${ }^{1}$

Poloha sa nachádza na východnom okraji mesta, na juhovýchodnom svahu terénnej vyvýšeniny rozprestierajúcej sa na lavej strane bývalého mŕtveho ramena rieky Nitry. Hrob (1/89) bol zistený na rozlahlej ploche vyloženej betónovými panelmi $\mathrm{v}$ dodatočne vyhĺbenom kanáli, pričom iniciatívny nálezca vyhotovil aj jeho nákres. Pri následných prácach bol už prítomný pracovník múzea J. Liszka, ktorý odkryl druhý inhumačný hrob (2/89) zasahujúci pod zastavanú plochu (obr. 2: B; tab. 3: C). V obidvoch prípadoch sa podarilo $\mathrm{v}$ pôdoryse zdokumentovat' približne polovicu hrobovej jamy v dížke $60 \mathrm{~cm} \mathrm{~s}$ podobnou šírkou $50 \mathrm{~cm}$, ako aj híbkou pohybujúcou sa okolo $110 \mathrm{~cm}$. Výskumom bolo získaných aj niekol'ko nevýrazných pravekých črepov z hrubostenných nádob, ktorých príslušnost' $\mathrm{k}$ hrobom je otázna. Rovnako nevyjasnený je vztah údajného ohniska, identifikovaného v ryhe v blízkosti hrobov, ktoré je znázornené na situačnom pláne výskumu. Výsledky záchrannej akcie neboli do odbornej literatúry doteraz uvedené a informuje o nich iba krátky príspevok uverejnený $\mathrm{v}$ miestnej tlači akcentujúci pohotovost' a ochotu pracovníka panelárne ohlásit nález múzeu (Liszka 1989, 3). Vzhladom na kuriózne okolnosti objavu, ako aj dokumentovanú híbku jám, je na mieste úvaha, že bol zachytený iba segment väčšejnekropoly, ktorá ostala po vybudovaní závodu „zakonzervovaná“ pod panelovou plochou (tab. 3: D).

\section{Hrob 1/89}

Údajne detský hrob porušený pri výkopových prácach orientovaný približne v osi ZJZ-VSV. Pri dolných končatinách jedinca skrčeného na pravom boku sa nachádzala misa (1), bronzová záušnica (2) a bronzové trubičky (3) z náhrdelníka (kresbová rekonštrukcia hrobu vychádza z náčrtu Františka Škoríka; tab. 3: A).

1. Polgulovitá misa s menším uchom pod okrajom a z vonkajšej strany šikmo skrojeným ústím. Vyhotovená $\mathrm{z}$ dobre plaveného materiálu s odtieňmi sivohnedej farby a čiernymi flakmi (tab. 3: 1). Rozmery: v. 90 mm; pr. ústia $215-235 \mathrm{~mm}$; pr. dna $80-85 \mathrm{~mm}$.

2. Liata bronzová záušnica sedmohradského typu vyhotovená z tenšej tyčinky, vyformovaná do srdcovitého tvaru s člnkovito zhrubnutými ramenami s nevýrazne zahrotenými koncami a so spätnou slučkou (tab. 3: 2). Rozmery: pr. $10 \mathrm{~mm}$; pr. tyčinky 1-2 mm.

3. Bronzové špirálovité trubičky salta leoni zo splošteného drôtu vo fragmentoch, 3 ks (tab. 3: 3, 4). Rozmery: pr. $5 \mathrm{~mm}$; š. plechu $3 \mathrm{~mm}$.

\section{Hrob 2/89}

Inhumačný hrob dospelého jedinca $\mathrm{v}$ skrčenej polohe na pravom (?) boku orientovaný v osi JZ-SV, ktorý bol pravdepodobne v minulosti sekundárne otvorený. Pod hlavou pochovaného bola uložená misa (1) a pri hlave sa našla koncentrácia zvieracích kostí. Medzi rebrovými kostami sa nachádzala bronzová ihlica (2) a pri dolných končatinách bronzové špirálové trubičky (3) z náhrdelníka (tab. 3: B).

\footnotetext{
1 L'udské kosti vyzdvihnuté z hrobov sú uložené v depozitári múzea a neboli predmetom antropologickej analýzy. Z tohto dôvodu nie je možné sa spolahlivo vyjadrit k veku ani k pohlaviu pochovaných.
} 


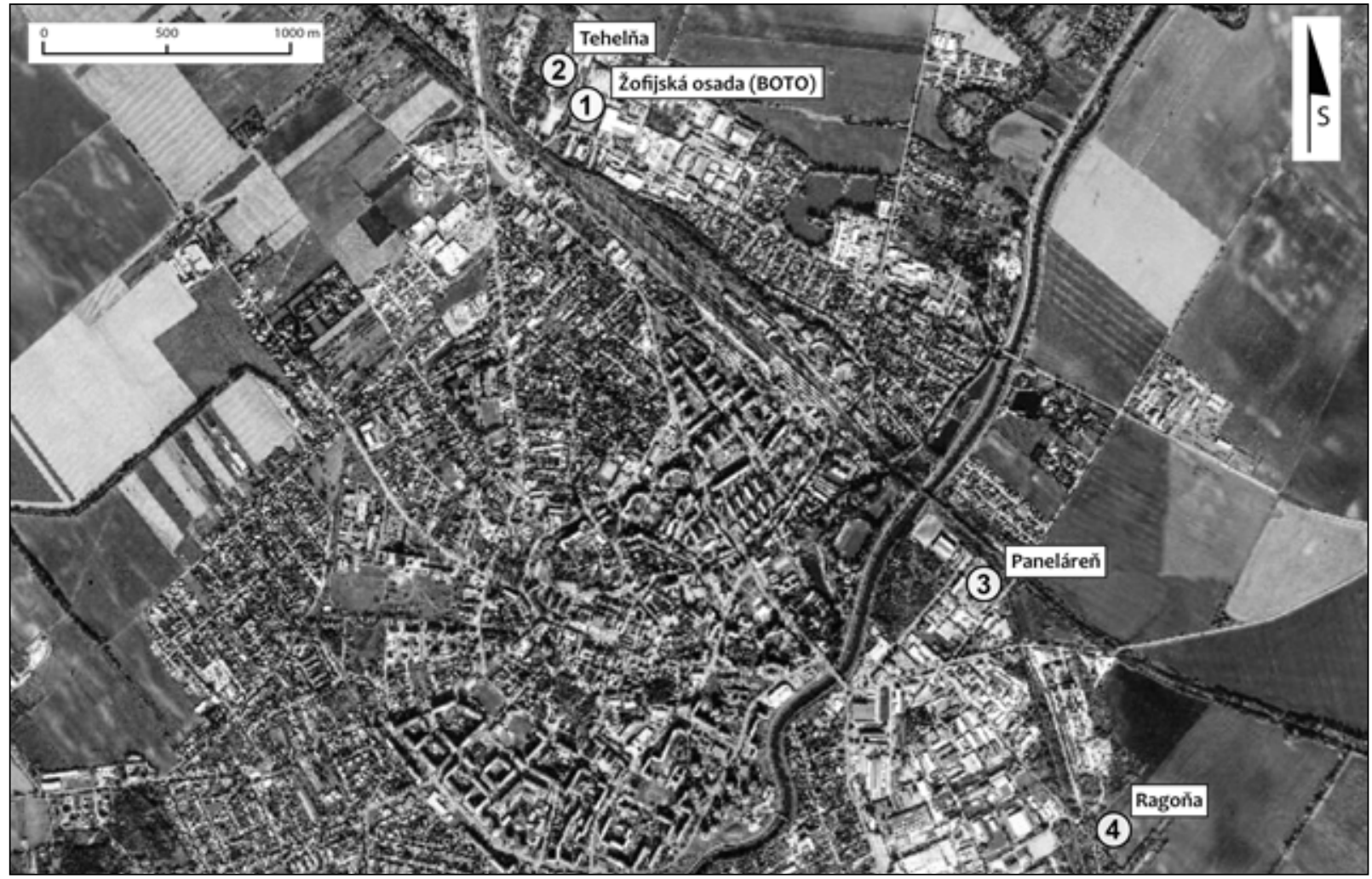

Obr. 1. Zvýraznené polohy s výskytom hrobov únětickej kultúry v Nových Zámkoch. 1 - Žofijská osada, areál firmy BOTO, výskum E. Kovácsovej v r. 2003; 2 - Tehelňa, výskum M. Rejholcovej v r. 1961; 3 - Paneláreň, výskum J. Liszku v r. 1989; 4 - Ragoňa, výskum M. Dušeka v r. 1958 (○ Google Earth; autor J. Godiš).
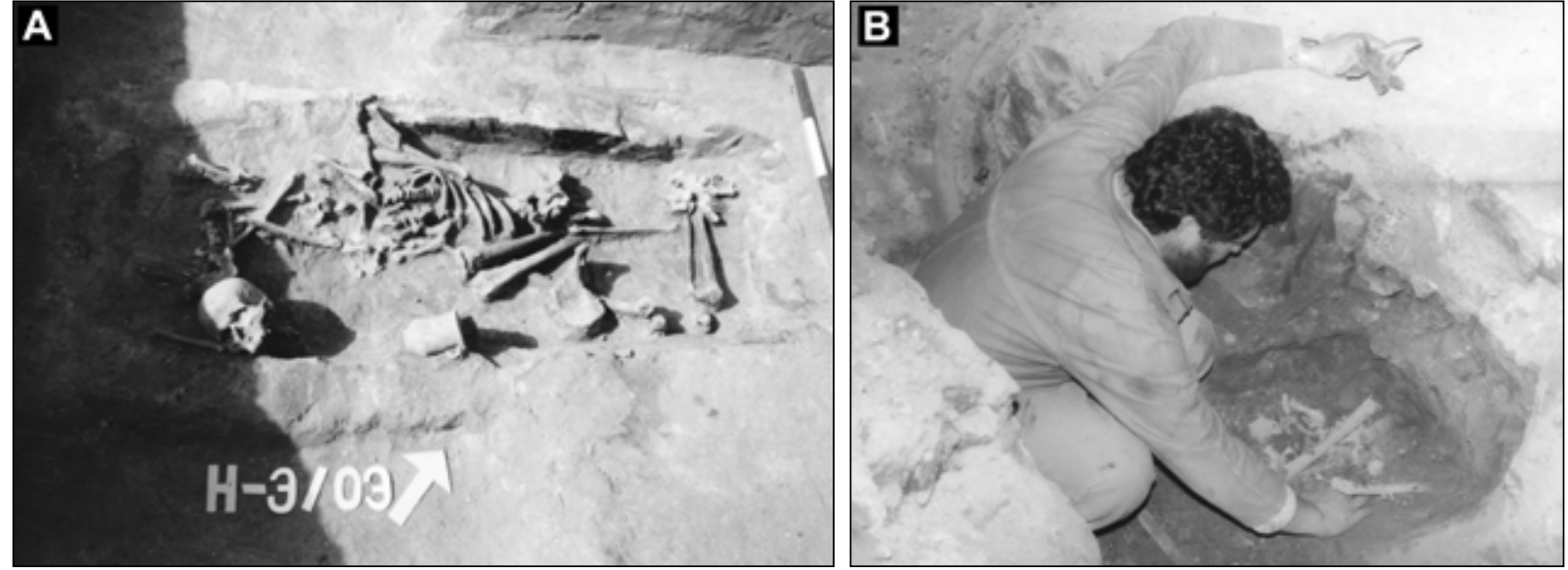

Obr. 2. Terénne fotografie hrobov únětickej kultúry v Nových Zámkoch. A - Žofijská osada, hrob 3/03; B - Paneláreň, hrob 2/89. Zdroj: Archív Múzea Jána Thaina v Nových Zámkoch.

1. Plochá kónická misa s pásikovým uchom pod okrajom vyhotovená z jemne plaveného materiálu sivohnedej farby (tab. 3: 9). Rozmery: v. $65 \mathrm{~mm}$; pr. ústia 260-270 mm; pr. dna 80-85 mm.

2. Bronzová ihlica s kornútovite, resp. rúrkovite stočenou hlavicou (poškodená). Hladká ihla kruhového prierezu je v spodnej tretine nepatrne zaoblená (tab. 3: 5). Rozmery: dí. $80 \mathrm{~mm}$; max. š. hlavice $7 \mathrm{~mm}$; dí. ihly $65 \mathrm{~mm}$.
3. Bronzové špirálovité trubičky salta leoni vo fragmentoch s rôznymi priemermi vinutia a šírkou plechu (5 ks) (tab. 3: 6, 7). Rozmery: pr. $6 \mathrm{~mm}$; š. plechu $3 \mathrm{~mm}(2 \mathrm{ks})$; pr. $3 \mathrm{~mm}$; š. plechu $2 \mathrm{~mm}$ (3 ks).

4. Schránka lastúrnika druhu Columbella s vyrezaným „srdcovitým“ ornamentom (?) na frontálnej strane a so stopami po uchytení pomocou bronzovej špirálovitej trubičky (tab. 3: 8). Rozmery: v. 13 mm; max. š. $8 \mathrm{~mm}$. 
V stálej archeologickej expozícii Múzea Jána Thaina sú vystavené artefakty zo staršej doby bronzovej vyzdvihnuté počas predstihového výskumu pod vedením E. Kovácsovej, ktorý prebiehal od marca do apríla 2003 v polohe Žofijská osada (areál firmy BOTO; obr. 1: 1). Opis nálezovej situácie trochsekundárne porušených inhumačných hrobov a ilustrácie inventára zverejnila autorka výskumu v informatívnej správe v ročenke AVANS (Kovácsová 2006, 116, 117, obr. 53: 7-11). Nálezy však neboli v tom čase predmetom osobitného rozboru a pri grafickej úprave príspevku $\mathrm{v}$ danom periodiku došlo tiež $\mathrm{k}$ znehodnoteniu jednej z podstatných kresieb bronzovej ihlice. $S$ ohladom na tieto skutočnosti je preto na mieste nanovo zverejnit relevantné hrobové celky (2/03 a 3/03; obr. 2: A; tab. 1: A, B) a predovšetkým zaujat' k nim odborné stanovisko $\mathrm{v}$ širšom kontexte.

Trojica hrobov v polohe Žofijská osada svedčí o existencii pohrebiska únětickej kultúry situovaného na severnom okraji mesta. Jeho areál v dôsledku neskoršieho polykultúrneho osídlenia a tiež pod vplyvom recentných zásahov (krátery po leteckých bombách, kanalizačné ryhy, sadovnícke jamy) utrpel výraznú devastáciu. Ešte v dobe bronzovej došlo do istej miery $\mathrm{k}$ jeho prevrstveniu pohrebiskom a blízko ležiacim sídliskom karpatskej mohylovej kultúry (Liszka 1984, 148). Nesporne najvýraznejší dopad malo neskôr založenie rozsiahlej slovansko-avarskej nekropoly so stovkami hrobov (Čilinská 1966, plán 1). Vari už nemôže byt pochýb o tom, že inhumačný hrob 5-B/61 (Benkovsky-Pivovarová 1999, 197-200), odkrytý počas výskumu M. Rejholcovej v roku 1961 na susediacej polohe Tehelňa (predtým známe aj ako „Belohorského záhrada“; obr. 1: 2), súvisí práve s hrobmi z výskumu E. Kovácsovej. Tie by zároveň predstavovali pokračovanie pohrebiska zo staršej doby bronzovej juhovýchodným smerom, zasahujúceho aj na plochu výskumu v roku 2003.

Jedinou zachovanou nádobou z výskumu je vysoký štíhly džbánok nájdený v hrobe 3/03, kde ležal disartikulovaný skelet mužského jedinca (maturus I; Jakab 2004, 93). Pomerne blízku paralelu, ale s plynulejšou profiláciou tela a odlišným nasadením ucha nachádzame $\mathrm{v}$ hrobe 31/58 na nekropole v polohe Ragoňa (Dušek 1969, tab. XI: 3). Kuvedenej lokalite, ktorá je v literatúre už dlhodobo známa, bude samostatne vyjadrených zopár poznámok v závere príspevku. Pri štýlovom rozbore nádoby zo Žofijskej osady je potrebné upriamit pozornost na jej nezvyčajnú tektoniku. Tá sa síce nesie v základných tendenciách hrnčiarstva únětickej kultúry vzdialene pripomínajúc vysoký variant tzv. klasických únětických šálok, napriek tomu však neobyčajný dôraz na jej vertikálny rozmer, výrazné zalomenie $\mathrm{v}$ spodnej časti tela a najmä aplikácia masívneho ucha pod okrajom (namiesto pri dne) bez pochýb figurujú $\mathrm{v}$ tejto kombinácii ako atypické prvky. Ich pôvod je treba najskôr hladat' $\mathrm{v}$ západnom kultúrnom prostredí, na čo už predtým poukázal jubilant J. Bátora $(2015,47)$, ktorý považuje dvojkónické hrnce so stlačenou dolnou častou, von vyhnutým okrajom a vel'kým pásikovým uchom na pleciach za vplyv z oblasti wieselburskej kultúry. Porovnatel'né nádoby s markantným zalomením v spodnej tretine nachádzame $\mathrm{v}$ hroboch mladšieho horizontu pochovávania (hrob 14 a 57) vo Vel'kom Grobe, ako aj v inventári hrobov z Vozokan (Benkovsky-Pivovarovál Chropouský 2015, tab. 89: 9; 98: 10; 108: B/IX, A/1, 2; Vladár 1969, 449, obr. 4). Od nálezu z Nových Zámkov sa ale všetky uvedené odlišujú čiastočne iným umiestnením ucha, a to približne $\mathrm{v}$ strede výšky tela nádoby. Možno stojí za pozornost' fakt, že exemplár z hrobu 3/03 má nasadenie ucha, ako i celkové stvárnenie do značnej miery podobné tomu, čo napríklad pozorujeme ešte na vysokých štíhlych hrncoch a bikónických amforách neskorej fázy nitrianskej kultúry (pozri Kuzma/Rajtár/Tirpák 1999, obr. 73: 2; Točík 1963, obr. 252: 5, 6).

Ďalší, evidentne intencionálne porušený hrob 2/03 obsahoval mladší variant bronzovej ihlice cyperského typu vyznačujúci sa krížovým špirálovitým ramenom (tab. 1: 1). Tie sa na našom území začínajú prvýkrát objavovat’ v čase klasickej fázy únětickej kultúry na pohrebiskách tzv. hurbanovskej skupiny (Bátora 2018, 181; Novotná 1980, 16), ako napríklad v ned’alekých Nesvadoch, v polohe Košikáreň (Dušek 1969, obr. 2: 5; 4: 2). Tu sa žiada len pripomenút, že s ohladom na výsledky novšieho teoretického výskumu sa javí používanie termínu „hurbanovská skupina“, resp. typ dnes už ako neopodstatnené2 (pozri Mitáš 2004, 295) a jeho uvádzanie má význam len v súvislosti s dejinami bádania. Faktom nad’alej ale ostáva, že pohrebiská ležiace v údolí rieky Nitry majú vzhladom na svoju periférnu polohu naozaj mierne odlišný charakter od zvyšku sídelného priestoru únětickej kultúry a na ich materiálnom prejave je viac badat vplyvy z vnútrokarpatskej oblasti (Bátora 2000, 550; Mitáš 2004, 293). Výskyt špecifických ihlíc cyperského typu sa viaže spravidla na hroby mužských jedincov (Bátora 2018, 183), avšak nález z Nových Zámkov tvorí v tomto prípade výnimku. Antropologická analýza chatrne zachovaného osteologického materiálu z hrobu 2/03 priniesla zistenie, že išlo asi o 30 až 40 ročnú osobu ženského pohlavia (adultus II; Jakab 2004, 93). Fragmenty špirálovitých trubičiek salta

\footnotetext{
2 „Historický vývoj v juhovýchodnej okrajovej zóne únětickej kultúry dnes už nie je potrebné atomizovat prostredníctvom "mikroentít", ktoré v konečnom dôsledku rušia obraz celkového dejinného vývoja určitej oblasti, ako napríklad v Ponitrí a Požitaví (Mitáś 2004, 295)."
} 
leoni z rovnakého hrobu (tab. 1:2-4), ako i bronzové šidlo z hrobu 3/03 (tab. 1: 6) nie sú chronologicky citlivými predmetmi a ich výskyt $\mathrm{v}$ tomto období je relatívne bežný.

Pri ukotvení datovania pohrebiska zisteného v roku 2003 je treba vziat do úvahy intaktný hrob 5-B/61 z polohy Tehelňa, ktorého výbava pozostávala z pohára hruškovitého tvaru, rozmernej plochej misy, výrazného bronzového šperku ${ }^{3}$ a tiež bronzovej triangulárnej dýky (tab. 2: 1-10). Tento dôležitý kontext považuje V. Mitáš (2013, 248, tab. XXV: 7-14) za reprezentanta klasickej fázy únětickej kultúry, $\mathrm{s}$ čím napokon korešponduje aj nález mladšieho variantu cyperskej ihlice z hrobu 2/03. O tom, že nešlo o solitérny hrob, napovedajú artefakty získané zberom $\mathrm{v}$ areáli tehelne (tab. 2: 11-13a), ako aj niektoré praveké hroby bez nálezov z výskumu v rokoch 1961-1962 (Benkovsky-Pivovarová 1999, 198).

Na základe dostupných údajov možno konštatovat', že na pohrebisku rozprestierajúcom sa v polohe Žofijská osada a v prilahlom areáli zaniknutej Kurzweilovej tehelne (neskôr Ponitrianskych tehelní) bola s určitostou zastúpená klasická fáza únětickej kultúry. Tá je na území juhozápadného Slovenska synchronizovaná so IV. horizontom pochovávania $\mathrm{v}$ Jelšovciach a $\mathrm{z}$ pohladu relatívnej chronológie zodpovedá modifikovanému stupňu BA2a (Bátora 2000, 550; 2018, obr. 65; Mitáš 2013, tabela 3). Otázkou do diskusie ostáva, či na pohrebisku možno rátat i so starším horizontom pochovávania, čo by mohol indikovat' práve džbánok $\mathrm{z}$ hrobu $3 / 03$. Absencia presvedčivých analógií podporuje záver, že azda ide o jedinečnú nádobu, ktorá reflektuje ovplyvnenie cudzou, najskôr západnou hrnčiarskou tradíciou (?). Tu treba podotknút, že na už zmienenom pohrebisku vo Vel'kom Grobe sa objavovala keramika wieselburskej kultúry spolu s nálezmi predklasickej fázy únětickej kultúry (Chropovský 1960, 115, 116; Vladár 1969, 452). Daný jav sa interpretuje ako dôsledok intenzívneho prenikania kultúrnych prvkov z oblasti medzi Neziderským jazerom a Dunajom na územie juhozápadného Slovenska, ktoré však kontinuálne pretrvávalo aj v priebehu klasickej fázy únětickej kultúry (Bátora 2018, 89; pozri mapu rozšírenia; Mitáš 2013, 251; Nagy 2013, obr. 1). V literatúre bola dávnejšie publikovaná fotografia bikónickej šálky bez bližších údajov o kontexte, ktorá mala pochádzat' z lokality Nové Zámky a je prisudzovaná práve predklasickej fáze sledovanej kultúrnej entity (Mitáš 2013, 260; Točík 1963, obr. 256:7). V spojitosti s tým je ale nevyhnutné uviest', že zaradenie daného nálezu do staršej doby bronzovej je mylné. Nádoba je totiž zhodná s kresbou šálky (dvojkónickej misy) zo žiarového hrobu 18 uverejnenej S. Stegmann-Rajtárovou (2009, 67, obr. 10: 1; tab. X: 7) pri príležitosti spracovania výskumu halštatského pohrebiska v polohe Ragoňa. Aktuálny stav výskumu preto zatial' nedisponuje žiadnymi jasnými dôkazmi o včasnejšom osídlení intravilánu Nových Zámkov v rámci vývoja únětickej kultúry.

Zachránené nálezy z polohy Paneláreň tvoria chronologicky homogénny súbor, ktorého datovanie je možné synchronizovat's pohrebiskom v polohách Žofijská osada a Tehelňa. Najvýraznejšie artefakty, ktorými je nepochybne starší variant liatej bronzovej záušnice sedmohradského typu z hrobu 1/89 (tab. 3: 2) ako i bronzová ihlica s kornútovite stočenou hlavicou z hrobu 2/89 (tab. 3: 5) patria k charakteristickým kovovým šperkom, ktoré sa začínajú na juhozápadnom Slovensku objavovat' práve $\mathrm{v}$ priebehu klasickej fázy únětickej kultúry (Bátora 2000, 409, 419; 2015, 67; 2018, 184; Novotná 1980, 19, 20). S takýmto datovaním súhlasí tiež sprievodná keramika, kde jednak typ hlbokej misy s postranným uškom ako i další plochý exemplár (tab. 3: 1,9) nesú svojské črty hrnčiarstva klasickej fázy únětickej kultúry a im príslušné analógie sú početne zastúpené napríklad na pohrebiskách situovaných na dolnom toku rieky Nitry (Nesvady, Hurbanovo, Bajč; Dušek 1969, 10-31; Točík 1979, 215-260). Zvláštnu pozornost' si vynucuje prívesok vyhotovený zo schránky lastúrnika druhu Columbella nájdený $\mathrm{v}$ hrobe $2 / 89$, ktorý pôvodne tvoril súčast' náhrdelníka, o čom svedčia zvyšky vsadenej bronzovej špirálovitej trubičky (tab. 3: 8). Pozoruhodný je obzvlášt ",srdcovitý“ ornament (?) vyrezaný na jeho frontálnej strane, ${ }^{4}$ ktorý zaiste nie je náhodný, nakol'ko porovnatelné spôsoby "výzdoby" tohto druhu malakofauny evidujeme $\mathrm{v}$ rôznych prehistorických obdobiach (pozri Cristiani 2013, 89-102, obr. 3; Ljuština/Krečković/Radišič 2019, 189-202, obr. 1). Išlo nielen o esteticky hodnotné artefakty, ale nepochybne aj o predmety s dnes už sotva identifikovatelným, hlbším symbolickým významom či magickou funkciou (viac Jelínek 2015, 62).

Posledné tu prezentované a zároveň prvé odborne skúmané pohrebisko $\mathrm{v}$ katastri mesta sa nachádzalo na jeho juhovýchodnom okraji v už spomínanej polohe Ragoňa, ktorá bola pôvodne pieskovou dunou medzi pravým brehom Žitavy a lavým brehom Nitry (obr. 1: 4). Ešte pred výskumom v rokoch 1957-1958 boli údajne do miestneho múzea odovzdávané predmety z tej istej

\footnotetext{
3 V. Mitáš $(2013,248)$ predpokladá, že výskyt bronzových srdcovitých a okuliarovitých záveskov v sledovanom období odráža kontakty únětickej kultúry so zadunajským kultúrnym okruhom.

4 Obdobný spôsob úpravy ekofaktu evidujeme aj na mušliach druhu Cardium v hrobe 5-B/61 v polohe Tehelňa, ktoré majú zhora vyvrtaný otvor na uchytenie (tab. $2: 4,5$ ).
} 
nekropoly (Točík 1979, 49), kedže sa tam od roku 1936 tažil piesok (Stegmann-Rajtár 2009, 58). Pokial' aj medzi nimi boli nálezy únětickej kultúry, ${ }^{5}$ tak boli zničené, prípadne stratené počas bombardovania mesta v závere 2 . svetovej vojny, kedy múzeum prišlo v podstate o takmer celú archeologickú zbierku. Výskumom M. Dušeka, ktorý bol primárne cielený na odkryv pohrebiska z doby halštatskej, sa podarilo zachytit aj čast' únětickej nekropoly a zdokumentovat' 9 inhumačných hrobov (Dušek 1969, 32-34, plán 2). Žial', majoritná čast’ z nich bola už v minulosti porušená zásahmi a iba zriedkavo sa $\mathrm{v}$ nich zachovali relevantné artefakty, ktoré by umožnili bližšie zadefinovat vnútornú chronológiu lokality (Dušek 1969, tab. XI). Napriek torzovitému materiálu, možno na nej podla V. Mitáša (2004, 293, tabela 2; 2013, tabela 3) rátat's dvomi etapami pochovávania, a to $\mathrm{v}$ klasickej a poklasickej fáze únětickej kultúry (horizont Jelšovce IV a V). Rovnakú situáciu evidujeme napríklad aj na nekropole v Nesvadoch, kde bolo preskúmaných až 90 hrobov.

Sumár hrobov únětickej kultúry z územia mesta Nové Zámky zretel'ne dokladá husté osídlenie daného mikroregiónu $\mathrm{v}$ priebehu pokročilého úseku stupňa BA2, t. j. v období jej klasickej fázy. Svedčí o tom koncentrácia minimálne trojice pohrebísk rozšírených $\mathrm{v}$ perimetri asi troch kilometrov, vynímajúc viacero významných nekropol v blízkom okolí (Bánov, Dvory nad Žitavou, Nesvady, Bajč). Na druhej strane nie sú za dnešného stavu bádania z intravilánu ani z okolia mesta evidované žiadne výraznejšie sídliskové nálezy, ktoré by sme mohli prisúdit k uvedeným funerálnym areálom. Nie je vylúčené, že rozhodujúca čast’ archeologických stôp po prítomnosti osád bola celkom zmazaná, eventuálne prevrstvená mestskou zástavbou zvlášt v čase vzniku protitureckej pevnosti v 16. a 17. storočí a potom kontinuálne vplyvom urbanizácie až do súčasnosti.

\footnotetext{
5 Medzi zachránenými nálezmi zo zbierky prof. Thaina je zastúpená aj tzv. klasická únětická šálka bez kontextu pochádzajúca údajne z lokality „Nové Zámky“" (tab. 2: 14).
} 


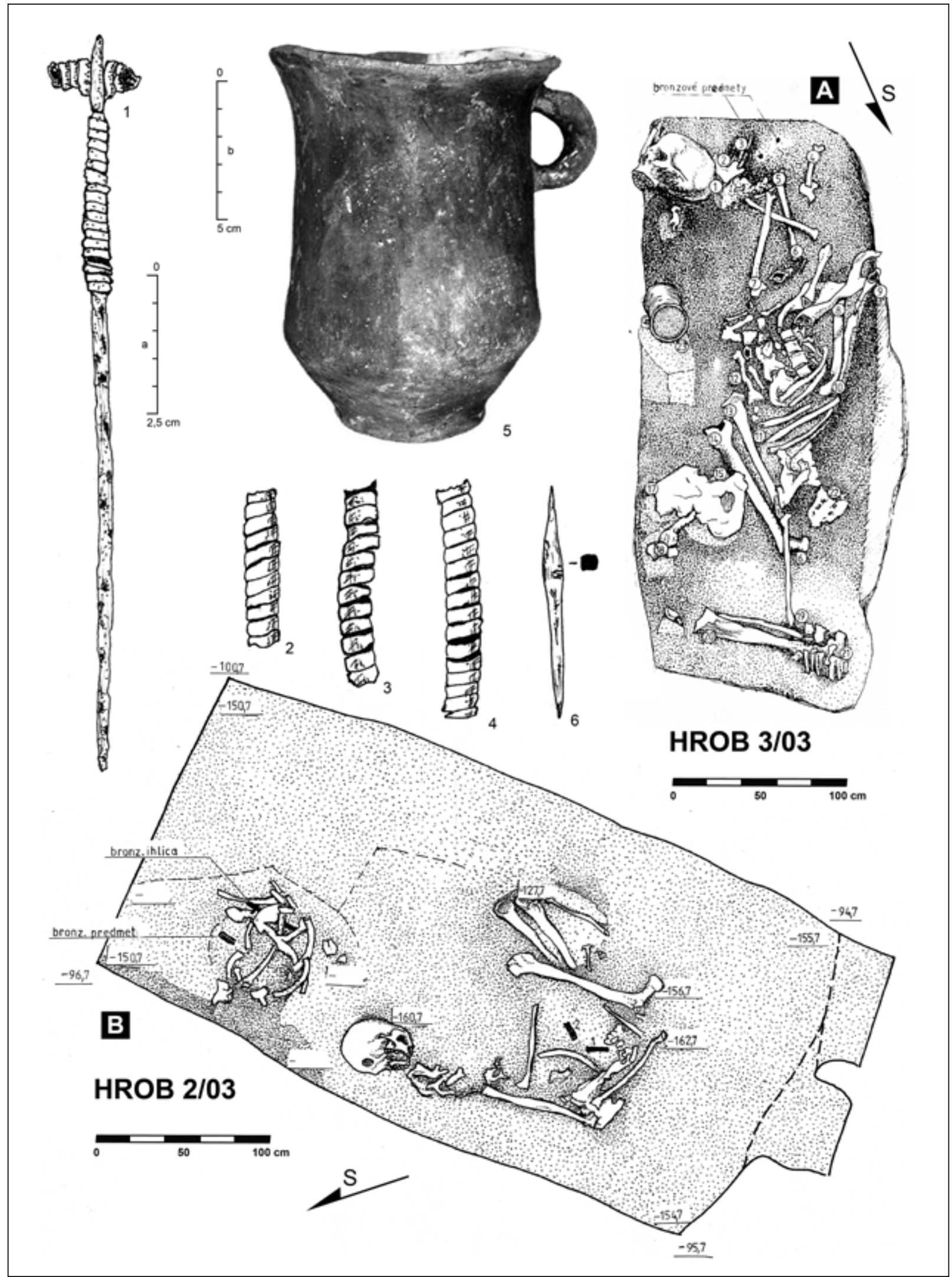

Tab. 1. Nové Zámky, poloha Žofijská osada (stavba BOTO, výskum E. Kovácsovej v r. 2003). 1-4, B - hrob 2/03; 5, 6, A - hrob 3/03. Mierka: a - 1-4, 6; b- 5 (kresby a plány L. Vincze; spracoval J. Godiš). 


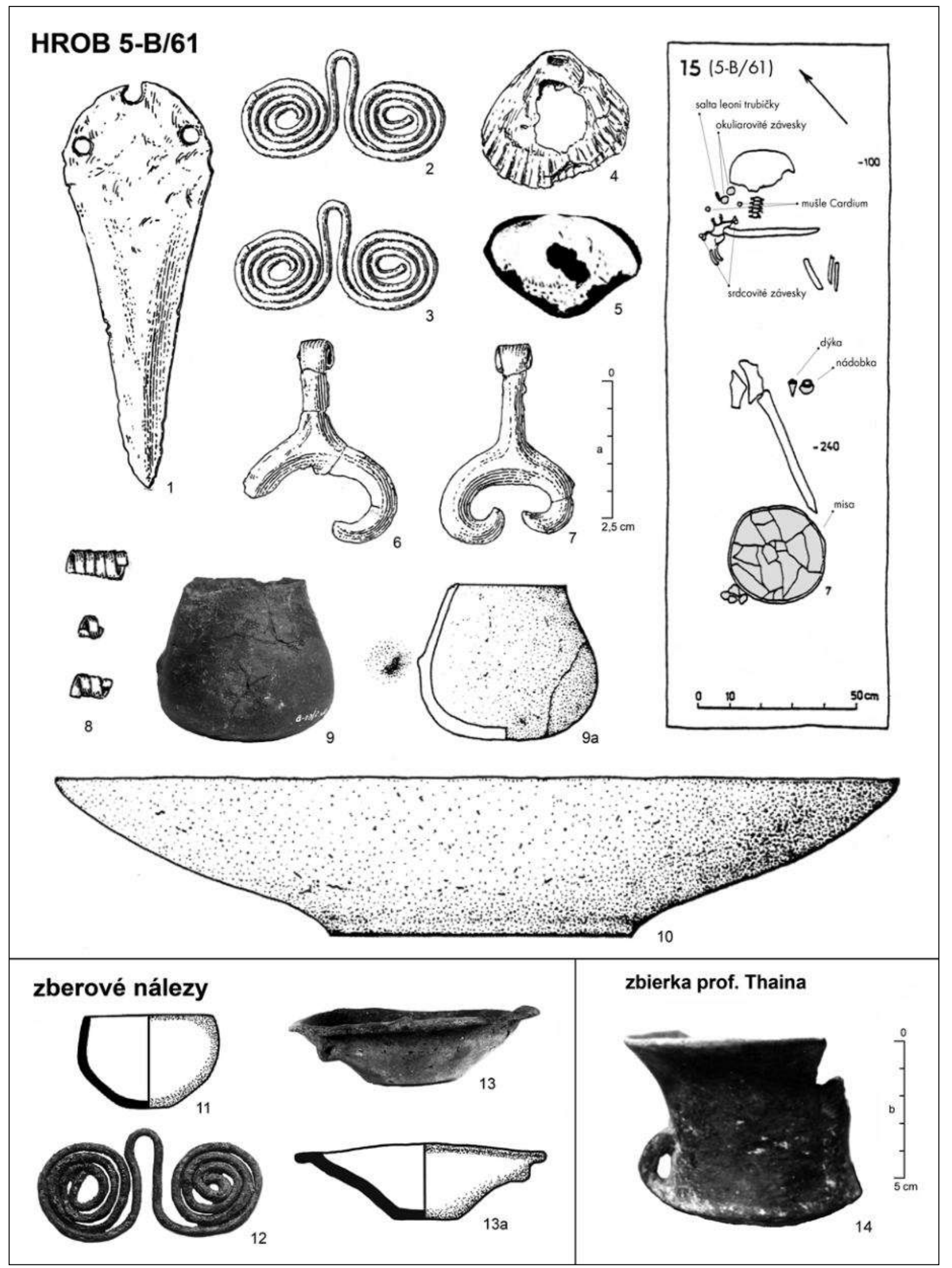

Tab. 2. Nové Zámky, poloha Tehelňa (výskum M. Rejholcovej v r. 1961). Inventár hrobu 5-B/61 (hrob 15), zberové nálezy (11-13a) a šálka zo zbierky prof. Thaina (14). Mierka: a - 1-8, 12; b - 9-11, 13, 14 (upravené a doplnené podl’a BenkovskyPivovarová 1999, obr. 1, 2; fotografie a spracovanie J. Godiš). 


\section{HROB 1/89}
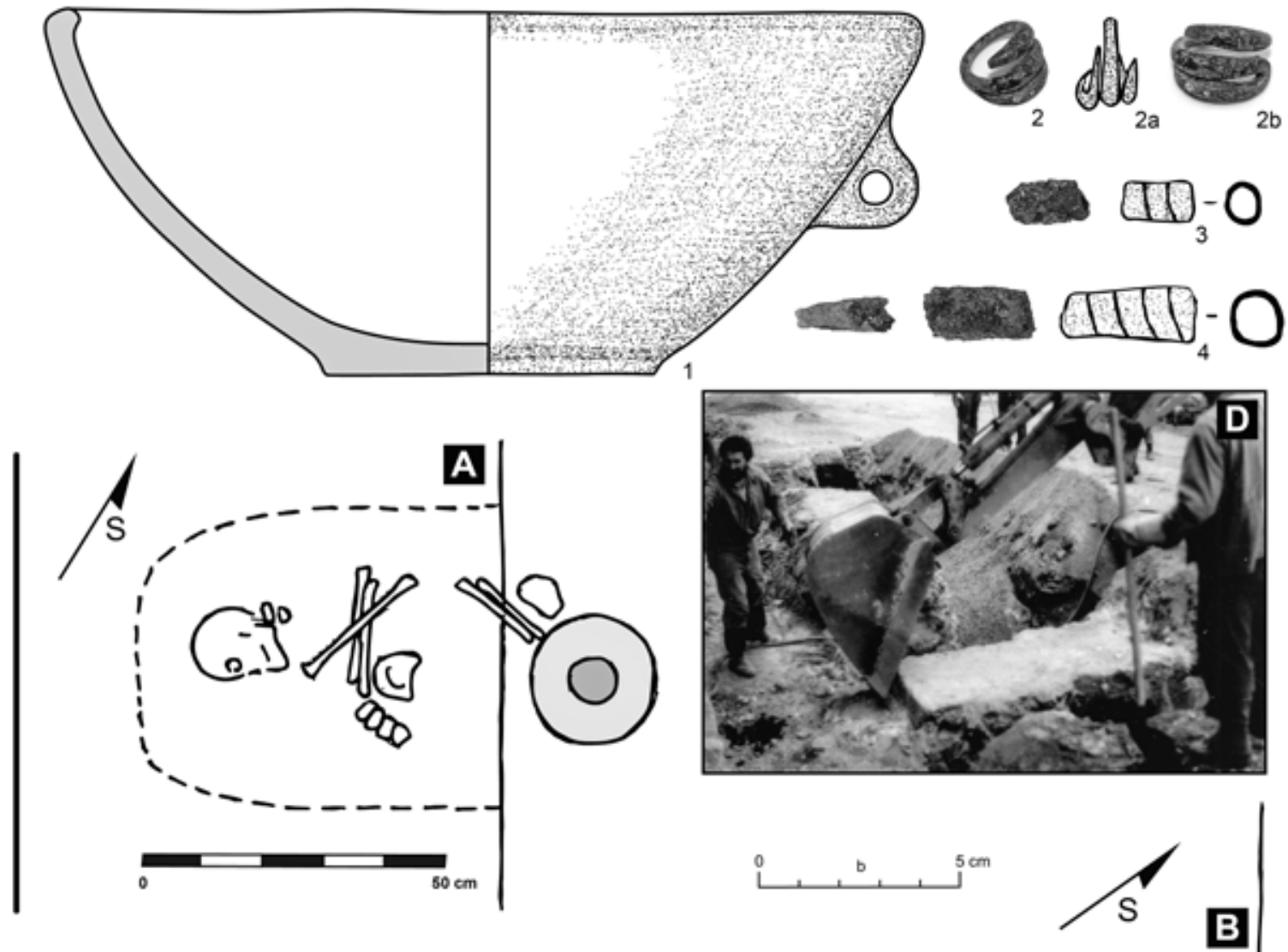

HROB 2/89

ohnisko (?)
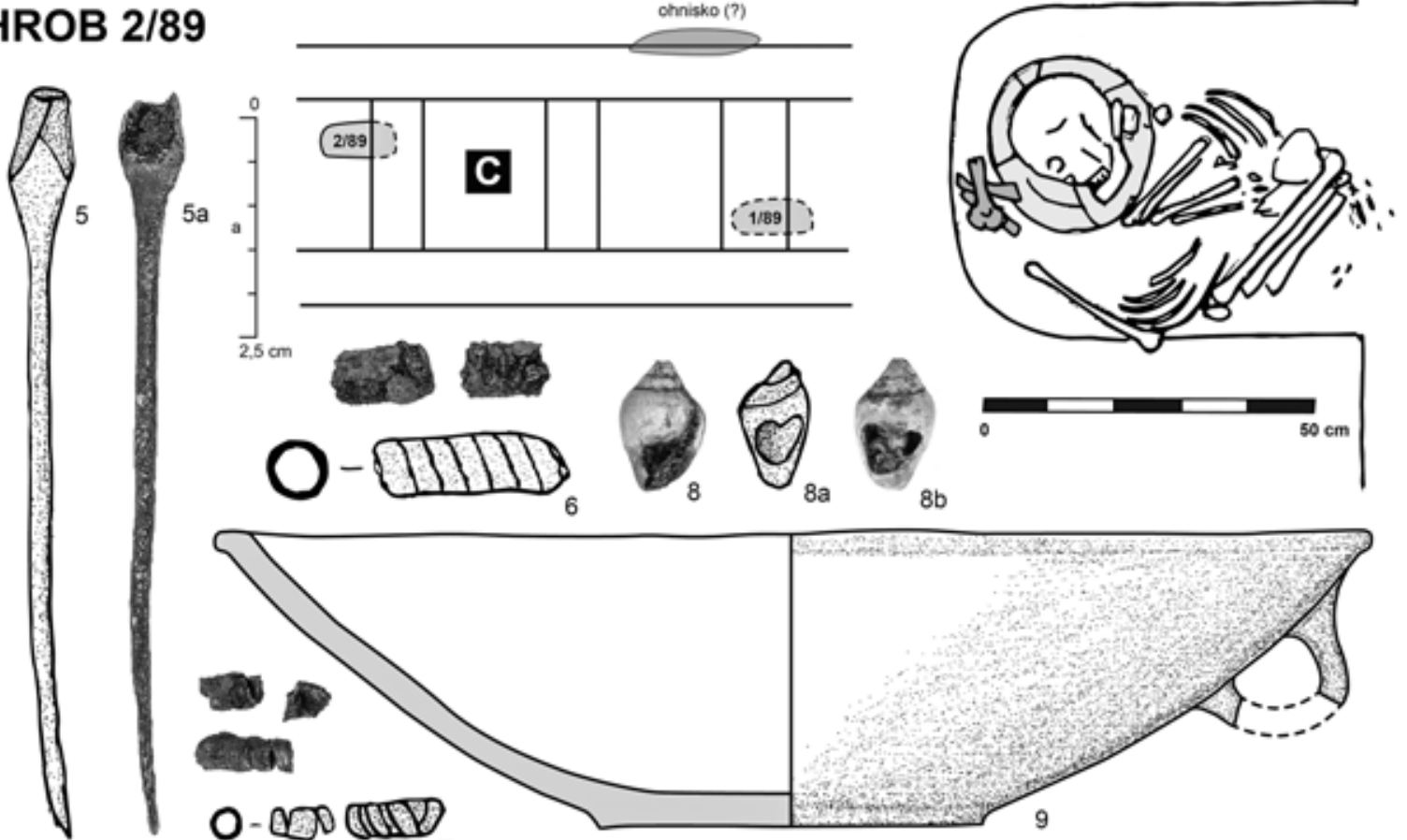

O-वागाए
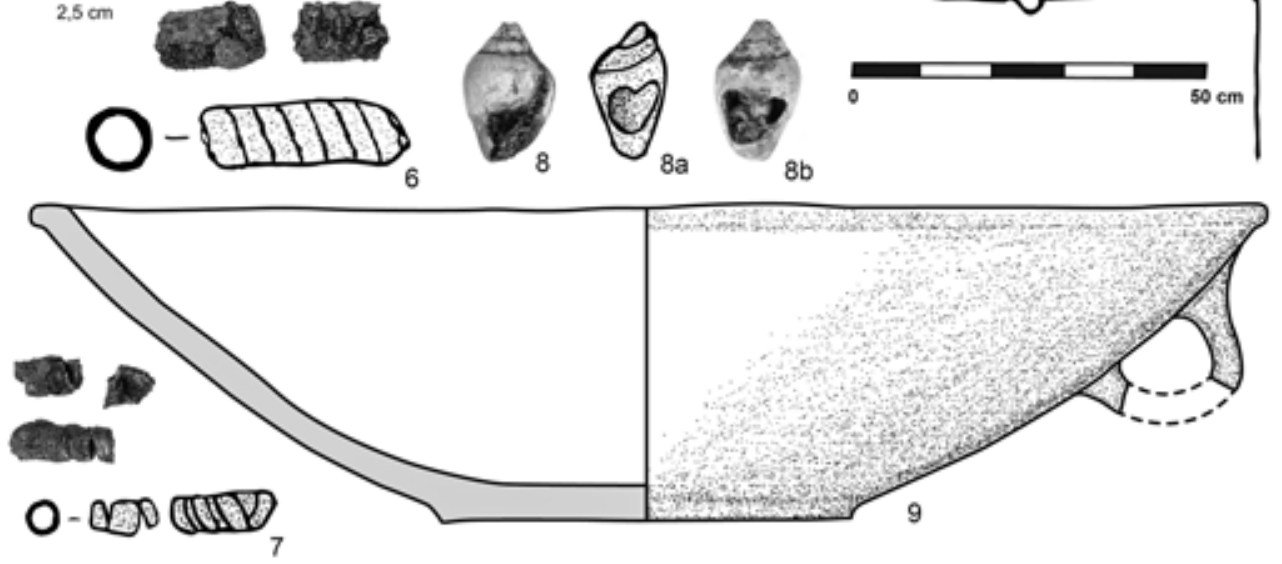

Tab. 3. Nové Zámky, poloha Paneláreň (pri Bešeňovskej ceste, výskum J. Liszku v r. 1989). 1-4, A - hrob 1/89; 5, 6, B - hrob 2/89; C - situačný plán výkopov a zachytených hrobov; D - odkryv betónových panelov na lokalite. Mierka: a - 2-8b; $\mathrm{b}-1,9$ (pôvodné kresby a plány J. Liszka; grafická úprava J. Godiš). 


\section{LITERATÚRA}

Bátora 2000 - J. Bátora: Das Gräberfeld von Jelšovce/Slowakei. Ein Beitrag zur Frühbronzezeit im nordwestlichen Karpatenbecken. Teil 1-2. PAS 16/1-2. Kiel 2000.

Bátora 2015 - J. Bátora: Kultúry staršej doby bronzovej: Artefakty. In: V. Furmánek (zost.): Staré Slovensko 4. Doba bronzová. Archaeologica Slovaca Monographiae. STASLO 4. Nitra 2015, 41-100.

Bátora 2018 - J. Bátora: Slovensko v staršej dobe bronzovej. Bratislava 2018.

Benkovsky-Pivovarová 1999 - Z. Benkovsky-Pivovarová: Zur Datierung des bronzezeitlichen Gräberfeldes von Nové Zámky-Ziegelei. In: J. Peška/J. Bátora (Hrsg.): Aktuelle Probleme der Erforschung der Frühbronzezeit in Böhmen und Mähren und in der Slowakei. Archaeologica Slovaca Monographiae. Communicationes 1. Nitra 1999, 197-200.

Benkovsky-Pivovarová/Chropovský 2015 - Z. Benkovsky-Pivovarová/B. Chropovský: Grabfunde der frühen und der beginnenden mittleren Bronzezeit in der Westslowakei. Teil 1-2. Archaeologica Slovaca Monographiae. Studia 21. Nitra 2015.

Chropovský 1960 - B. Chropovský: Pohrebisko zo staršej doby bronzovej vo Vel'kom Grobe. In: B. Chropovský/ M. Dušek/B. Polla: Pohrebiská zo staršej doby bronzovej na Slovensku. Archaeologica Slovaca Monographiae. Fontes 3. Bratislava 1960, 13-136.

Čilinská 1966-Z. Čilinská: Slawisch-awarisches Gräberfeld in Nové Zámky. Archaeologica Slovaca Monographiae. Fontes 7. Bratislava 1996.

Cristiani 2013 - E. Cristiani: Ornamental traditions of the late Pleistocene and Early Holocene foragers in the Eastern Alps: The Case of Riparo Biarzo. Gortania. Geologia, Paleontologia, Paletnologia 34/2012, 2013, 89-102.

Dušek 1969 - M. Dušek: Bronzezeitliche Gräberfeld in der Südwestslowakei. Archaeologica Slovaca Monographiae. Catalogi 4. Bratislava 1969.

Jakab 2004 - J. Jakab: Antropológia troch kostier z hrobov tzv. hurbanovského typu v Nových Zámkoch. AVANS 2003, 2004, 92-94.

Jelínek 2015 - P. Jelínek: Sladkovodné lastúrniky a ich symbolika v Mad’arovskej kultúre. In: J. Bartík (ed.): Zborníkna pamiatku Jozefa Paulíka: štúdie. Zborník SNM. Archeológia. Supplementum 9. Bratislava 2015, 53-76.

Rukopis prijatý 2. 6. 2020

Translated by Jakub Godiš
Kovácsová 2006 - E. Kovácsová: Záchranné výskumy na území mesta Nové Zámky. AVANS 2004, 2006, 116-119, 263-265.

Kuzma/Rajtár/Tirpák 1999 - I. Kuzma/J. Rajtár/J. Tirpák: Záchranný výskum vo Vel'kom Kýri. AVANS 1997, 1999, 99-101.

Liszka 1984 - J. Liszka: Záchranné výskumy a prieskumy v Nových Zámkoch. AVANS 1983, 1984, 147-149, 293, 294.

Liszka 1989 - J. Liszka: Titkairól vall a föld (Zem prezrádza svoje tajomstvá). Heti Hírlap/Naše Novosti (16.5.1989) 29/20, 1989, 3.

Ljuština/Krečković/Radišič 2019 - M. Ljuština/M. Krečković/T. Radišič: Notes on Columbella Shells from the Bronze Age Necropolis Mokrin, Northern Serbia. In: V. Sîrbu/A. Comşa/D. Hortopan (eds.): Digging in the Past of Old Europe. Studies in Honor of Cristian Schuster at his $60^{\text {th }}$ Anniversary. Editura Istros a Muzeului Brăilei "Carol I". Târgu Jiu - Brăila 2019, 189-202.

Mitáš 2004 - V. Mitáš: K niektorým otázkam tzv. hurbanovského typu. Slovenská archeológia 52, 2004, 281-300.

Mitáš 2013 - V. Mitáš: Expanzia únětickej kultúry so zretel’om na nálezy z územia Slovenska. Slovenská archeológia 61, 2013, 203-321.

Nagy 2013 - M. Nagy: Der südlichste Fundort der Gáta-Wieselburg-Kultur in Zsennye-Kavicsbánya/Schottergrube, Komitat Vas, Westungarn. Savaria 36, 2013, 75-173.

Novotná 1980 - M. Novotná: Die Nadeln in der Slowakei. PBF XIII/6. München 1980.

Stegmann-Rajtár 2009 - S. Stegmann-Rajtár: Žiarové pohrebisko východohalštatskej a vekerzugskej kultúry v Nových Zámkoch. Príspevok k pohrebiskám z doby halštatskej vo východoalpsko-zadunajskej oblasti. Slovenská archeológia 57, 2009, 57-116.

Točík 1963 - A. Točík: Die Nitra-Gruppe. Archeologické rozhledy 15, 1963, 716-774.

Točík 1979 - A . Točík: Výčapy - Opatovce a d’alšie pohrebiská zo staršej doby bronzovej na juhozápadnom Slovensku. Nitra 1979.

Vladár 1969 - J. Vladár: K otázke zásahu wieselburskej kultúry na území Slovenska. Archeologické rozhledy 21, $1969,448-459$.

Mgr. Jakub Godiš, PhD.

Múzeum Jána Thaina v Nových Zámkoch

Pribinova 6

SK - 94062 Nové Zámky

kubo.godis@gmail.com 


\title{
Burial Sites of Únětice Culture in Nové Zámky
}

\author{
Jakub Godiš
}

SUMMARY

The aim of this paper is to make available and evaluate the so far unpublished findings of disturbed graves and also discuss the previously known burials of the Únětice culture in Nové Zámky, which were documented during the field excavation of the local museum and Institute of Archaeology SAS. These were discovered in various areas of town and they are currently in the already built up peripheral zones within the its limits (Fig. 1). A preserved grave goods from these burials give clear proof that this microregion was densely populated, especially during the advanced stage of the BA2 period, i.e. the classical phase of the Únětice culture. The concentration of at least

Fig. 1. Highlighted sites with Únětice culture burials in Nové Zámky. 1 - Žofijská osada, area of the BOTO company, excavation of E. Kovácsová in 2003; 2 - Tehelňa, excavation of M. Rejholcová in 1961; 3 - Paneláreň, excavation of J. Liszka in 1989; 4 - Ragoňa, excavation of M. Dušek in 1958 (○ Google Earth, author J. Godiš).

Fig. 2. Field photographs of Únětice culture burials in Nové Zámky. A - Žofijská osada, grave 3/03; B - Paneláreň, grave 2/89. Source: Archive of Ján Thain Museum in Nové Zámky.

Pl. 1. Nové Zámky, location Žofijská osada (BOTO construction, excavation of E. Kovácsová in 2003). 1-4, B - grave 2/03. 5, 6, A-grave 3/03. Scale: $a-1-4,6 ; b-5$ (drawings and plans by L. Vincze; editing by J. Godiš). three burial sites, spread in the perimeter of circa three kilometres gives evidence of that - notwithstanding the several important necropoli in the vicinity in Bánov, Dvory nad Žitavou, Nesvady and Bajč. On the other hand, in the current state of research, there were no noticeable settlement findings registered neither within the town limits nor in the vicinity, which could be credited to the already mentioned burial sites. It is also possible that a decisive part of the archaeological traces of the settlements was completely erased, or perhaps overlaid by the urban centres, especially when the star-shaped fortress was built in modern history.

Pl. 2. Nové Zámky, location Tehelňa (excavation of M. Rejholcová in 1961). Inventory of the grave 5-B/61 (grave 15), stray finds from the site (11-13a) and cup from prof. Thain's collection (14). Scale: a $-1-8,12$; b - 9-11, 13, 14 (modified and updated according to Benkovsky-Pivovarová 1999, fig. 1, 2; photos and editing by J. Godiš).

Pl. 3. Nové Zámky, location Paneláreň (by Bešeňovská road, excavation of J. Liszka in 1989). 1-4, A - grave $1 / 89 ; 5,6$, B - grave 2/89; C - situation plan of excavations and identified graves; D - uncovering of concrete panels on site. Scale: $a-2-8 b ; b-1,9$ (original drawings and plans by J. Liszka; graphic editing by J. Godiš). 